\title{
"Corporate brand image and switching behavior: case of mobile telecommunications customers in Zimbabwe"
}

\begin{tabular}{|c|c|}
\hline AUTHORS & $\begin{array}{l}\text { Shylet Chigwende } \\
\text { Krishna Govender } \text { (D https://orcid.org/0000-0002-3079-5989 } \\
\text { R http://www.researcherid.com/rid/U-1710-2017 }\end{array}$ \\
\hline ARTICLE INFO & $\begin{array}{l}\text { Shylet Chigwende and Krishna Govender (2020). Corporate brand image and } \\
\text { switching behavior: case of mobile telecommunications customers in Zimbabwe. } \\
\text { Innovative Marketing , 16(2), 80-90. doi:10.21511/im.16(2).2020.07 }\end{array}$ \\
\hline DOI & http://dx.doi.org/10.21511/im.16(2).2020.07 \\
\hline RELEASED ON & Wednesday, 10 June 2020 \\
\hline RECEIVED ON & Tuesday, 14 April 2020 \\
\hline ACCEPTED ON & Thursday, 28 May 2020 \\
\hline LICENSE & $\begin{array}{l}(c) \text { EY } \\
\text { This work is licensed under a Creative Commons Attribution } 4.0 \text { International } \\
\text { License }\end{array}$ \\
\hline JOURNAL & "Innovative Marketing " \\
\hline ISSN PRINT & $1814-2427$ \\
\hline ISSN ONLINE & $1816-6326$ \\
\hline PUBLISHER & LLC "Consulting Publishing Company "Business Perspectives" \\
\hline FOUNDER & LLC "Consulting Publishing Company "Business Perspectives" \\
\hline
\end{tabular}

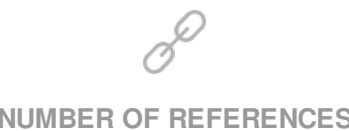

49

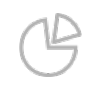

NUMBER OF FIGURES

1

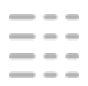

NUMBER OF TABLES

3

(C) The author(s) 2023. This publication is an open access article. 


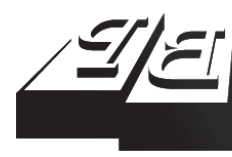

\section{BUSINESS PERSPECTIVES}

(O)

LLC "CPC "Business Perspectives" Hryhorii Skovoroda lane, 10, Sumy, 40022, Ukraine www.businessperspectives.org

Received on: $14^{\text {th }}$ of April, 2020 Accepted on: $28^{\text {th }}$ of May, 2020 Published on: $10^{\text {th }}$ of June, 2020

(c) Shylet Chigwende, Krishna Govender, 2020

Shylet Chigwende, Ph.D. Student, Lecturer, School of Management, Information Technology and Governance, University of KwaZuluNatal, South Africa.

Krishna Govender, Ph.D., Professor, School of Management, Information Technology and Governance, University of KwaZulu-Natal, South Africa.

\section{CORPORATE BRAND IMAGE AND SWITCHING BEHAVIOR: CASE OF MOBILE TELECOMMUNICATIONS CUSTOMERS IN ZIMBABWE}

\begin{abstract}
Mobile telecommunication service providers in Zimbabwe are using a brand image to market their products and minimize brand switching, resulting from increased market competition. A cross-sectional survey was conducted among a convenience sample of 385 participants in Zimbabwe. The sample size was determined using Rao software sample size calculator to extract an acceptable sample from apopulation of 1,973,906 inhabitants. Data were collected using a five-point Likert scale questionnaire and were also tested for reliability and validity using SPSS version 20. It was ascertained that $70 \%$ of the respondents' switched SIM cards, $20 \%$ never switched, and $10 \%$ were in different to the different providers. Structural Equation Modeling (SEM) showed that mobile network service providers' brand image positively affects customer satisfaction, a positive relationship exists between mobile network service providers' brand image and consumer brand switching behavior, customer satisfaction positively affects their loyalty. Corporate brand image indirectly affects customer loyalty through customer satisfaction. The researchers recommend marketers to consider the findings when designing strategies for marketing mobile network services.
\end{abstract}

\section{Keywords mobile telecommunication, brand image, customer loyalty, customer satisfaction}

JEL Classification M31, M37

\section{INTRODUCTION}

Globalization has led to technological advancements, especially in the mobile telecommunications sector, which has resulted in increased competition, such that service providers resort to using the brand image to market their products (Zhang, 2015). Marumbwa (2013) argues that several brands exist in the mobile telecommunications global village, and consumers make their purchase decision depending on their perception of the brand image. Competition is also high among three mobile service providers in Zimbabwe, namely, Econet Wireless Zimbabwe, Netone, and Telecel Zimbabwe (Karombo, 2017). Telecommunications companies in Zimbabwe are governed by the Postal and Telecommunications Authority of Zimbabwe (POTRAZ), which was formed under the Postal and Telecommunications Act in 2000 (POTRAZ Report, 2012).

According to POTRAZ Report (2016), there are 20,239,805 mobile telecommunication subscribers in Zimbabwe, and 12,696,303 are active. However, although Zimbabwe has a total population of 15 million, the number of mobile telecommunication subscribers exceeds this total, thus supporting the view of Marumbwa (2013) that subscribers pur- 
chase Subscriber Identity Module (SIM) cards from different mobile telecommunication suppliers, and also switch brands frequently.

The growth of the mobile telecommunications industry has been hampered by the harsh economic conditions currently prevailing in Zimbabwe, and the annual revenue is reported to be falling steadily (Karombo, 2017), and brand switching is common amongst mobile network users in Zimbabwe, as noted by Marumbwa (2013). Consumers use brand image to make their choices from amongst different brands (Rahman, Haque, \& Khan, 2012). It is easier and cheaper to acquire SIM cards and also switch mobile network service providers in Zimbabwe's mobile telecommunications industry. Consumers also have multiple SIM cards and this allows temporary brand switching to occur. Mobile network service provider brand switching occurs regularly and its a very common habit in Zimbabwe's telecommunications industry. Consumer switching behavior has a huge negative impact on organisation's growth and profitability. The mobile telecommunications industry is important in Zimbabwe as it is at the heart of the development of almost all the strategic economic sectors which include agriculture, manufacturing, and mining industry. Several studies have been conducted on brand image and consumer behavior (Tekin, Yiltay, \& Ayaz, 2016; Zhang, 2015). The researchers mentioned above paid more significant attention to the relationship between brand image and purchasing decisions, commitment, trust, and attitude.

Despite these increased interests in branding and consumer behavior, little empirical literature is available on the effect of corporate brand image on consumer switching, loyalty, and satisfaction. Instead, the focus among several authors regarding brand switching was on the impact of and factors influencing brand switching (Nimako, 2012; Awogbemi, 2015). More specifically, no research was conducted on corporate brand image and satisfaction of customers and consumer switching in the mobile telecommunications sector in Zimbabwe.

This research, therefore, adds to the body of knowledge by investigating the relationship between corporate brand image and consumer loyalty, customer satisfaction, and consumer switching in Zimbabwe's mobile telecommunications sector. The overall aim of the study is to ascertain how corporate brand image affects consumer buying behavior in the mobile telecommunications sector of Zimbabwe.

\section{LITERATURE REVIEW AND HYPOTHESES DEVELOPMENT}

\subsection{Mobile network operators in Zimbabwe}

The telecommunications industry's deregulation in the 1990s led to the entry of three big mobile operators into Zimbabwe registered with POTRAZ, namely, Econet Wireless Zimbabwe, Telecel Zimbabwe, and NetOne (Viriri \& Phiri, 2017). Mobile network operators are the owners of a network structure, and they are also the retailers of airtime to the consumers (Van Der Merwe, 2015). Nhundu (2017) argued that the companies in the telecommunications sector of Zimbabwe are slow in adopting advanced technologies; hence, there is low innovation, poor service quality, and high prices.
There are over 20 million mobile telecommunications subscribers registered with POTRAZ (POTRAZ Report, 2016). The growth of the mobile telecommunications industry in Zimbabwe has been hampered by the harsh economic conditions prevailing in Zimbabwe, and the annual revenue is reported to be falling steadily (Karombo, 2017). The mobile telecommunications industry of Zimbabwe is difficult to penetrate because of the high license fees and high capital requirements, which is a big barrier of entry (Nhundu, 2017). This researcher further added that there might be new competitors in the long run since POTRAZ is encouraging the sharing of infrastructure amongst the competing companies.

According to Marumbwa (2013) and Karombo (2017), there has been stiff competition among the three mobile network operators in Zimbabwe in the past few years, and the companies have been 
employing aggressive promotional activities like free calls, free short messages (SMS), and reduced tariffs at chosen time frames, to gain a large market share. The mobile sector is the main driver of the economy of Zimbabwe; it has contributed to about $77 \%$ of the growth of the economy (Karombo, 2017). High competition in the telecommunications sector is forcing the operators to lower prices and provide better packages as they fight for customers in the difficult economy of Zimbabwe (Nhundu, 2017).

There are many promotional activities and intense competition in the telecommunications sector, and subscribers can easily switch network providers (Nhundu, 2017). This researcher further added that it is cheaper and simpler to switch network providers in Zimbabwe, and subscribers are allowed to retain their mobile telephone numbers when they switch service providers.

\subsection{Brands and brand switching}

A brand is a term or any symbol that distinguishes the sellers' goods and services from the goods and services of other sellers (Kotler \& Keller, 2015), and the brands directly impact consumers' buying behavior. According to Lee, James, and Kim (2014), brand image is avital element of branding. Zhang (2015) highlighted that customers make their buying decisions based mainly on the image of a brand, and branding is an important concept in understanding consumer behavior. According to Kotler and Keller (2012), consumer behavior is when consumers select, buy, or consume goods and services to satisfy their needs and wants. Romani, Grappi, and Dali (2012) argue that consumers display different behaviors towards different brands, and it is important to study their behavior.

Das, Prakrash, and Khattri (2016) postulated that consumers face a big challenge when choosing a mobile service provider, and the brands have a direct impact on their behavior. Rahman, Haque, and Hussain (2013) indicated that brand image is the most important factor used by consumers in choosing their preferred goods and services, after getting information about a certain brand and other available alternatives. Today's consumers have much information, which affects their brand choices and preferences, and they face a di- lemma in choosing a specific network provider or the best brand (Marumbwa, 2013). According to these researchers, brands are being used as a selection criterion; consumers base their decisions on the brand image. Das et al. (2016) added that the brand image is the main driver of consumer's perceptions and thoughts of the product, and this also has a great impact on their consumption behavior.

Sultama (2012) defines brand switching as the process whereby consumers change from buying one brand to another. Sultama (2012) and Nimako (2012) reported that switching from one brand to another is very easy in the telecommunications sector. Nimako (2012) further reported that due to the proliferation of mobile devices at cheap costs, consumers can use the same number on different mobile telecommunication networks, and can easily switch networks. Thus, there is a need to investigate how corporate brand image affects consumer behavior in the mobile telecommunications sector, where consumers are overwhelmed with choices.

\subsection{Corporate brand image and customer satisfaction}

According to Srivastava and Sharma (2013), apositive corporate brand image can improve sales through increased customer satisfaction. Lahap, Ramli, Saed, and Zain (2016) argued that corporate brand image has a great impact oncustomer satisfaction. Ene and Ozkaya (2014) argued that a positive relationship exists between corporate brand image and customer satisfaction. Therefore, it is hypothesized that:

H1: The mobile telecommunication network service providers' brand image has a positive impact on customer satisfaction.

\subsection{Corporate brand image and customer loyalty}

According to Richard and Zhang (2012), a corporate brand image has an impact on customer loyalty. Srivastava and Sharma (2013) argue that favorable corporate brand image increases sales through improved customer loyalty. Corporate brand image stimulates customer loyalty, and customer loyalty plays a big role in building a positive corporate 
brand image (Kariuki, 2015). This researcher further added that an organization's brand image has a great effect on customer loyalty. Rahman et al. (2012) argued that brand image positively impacts customer loyalty in three sectors: telecommunications industry, retail industry, and education industry. Neupane (2015) and Ranjbarian, Sanayel, Kaboli, and Hadadian (2012) agree that there is a strong relationship between an organization's brand image and customer loyalty. According to Yu and Ramathan (2012), a corporate brand image plays a big role in maintaining customer loyalty. Therefore, it is hypothesized that:

H2: In the mobile telecommunications sector, the corporate brand image positively affects consumer loyalty.

\subsection{Corporate brand image and consumer switching}

Srivastava and Sharma (2013) argue that a favorable organization's brand image reduces consumer switching behavior. Saeed and Azmi (2015) argued that any corporate brand image element that touches on religion influences consumers' switching to another brand. Therefore, it is hypothesized that:

H3: In the mobile telecommunications sector, corporate brand image positively affects consumer brand switching.

\subsection{Customer satisfaction and loyalty}

Sekyere (2015) and Richard and Zhang (2012) agree that customer satisfaction positively affects customer loyalty. According to Seto-Pamies (2012), customer satisfaction is a vital element in customer loyalty. Srivastava and Sharma (2013) further added that customer satisfaction directly affects customer loyalty. Adonyeva (2012) argued that dissatisfied customers could move to another company. Martins, Hor-Meyll, and Ferreira (2013) argued that customer satisfaction is a powerful sign of customer loyalty. Therefore, it is hypothesized that:

H4: In the mobile telecommunications industry, customer satisfaction positively affects customer loyalty.

\subsection{Customer satisfaction and switching behavior}

According to Seto-Pamies (2012), high levels of customer satisfaction reduces consumer brand switching. Satisfied customers are most likely to urge other customers to buy, and they may not move to other brands (Kariuki, 2015). Therefore, it is hypothesized that:

H5: In the mobile telecommunications industry, customer satisfaction affects consumer brand switching.

\subsection{Corporate brand image, customer satisfaction, and consumer switching behavior}

According to Kariuki (2015), if customers are satisfied by the company's products and services, and there is a positive corporate brand image, there is less probability of consumer switching. Thus, it is hypothesized that:

H6: In the telecommunications industry, a corporate brand image has an impact on consumer brand switching behavior through customer satisfaction.

\subsection{Corporate brand image, customer loyalty, and customer satisfaction}

According to Ekorn and Khan (2014), corporate brand image and satisfaction of customers have a positive impact on customer loyalty. Richard and Zhang (2012) argued that an organization's brand image affects customer loyalty, and they are mediated by customer satisfaction. Kariuki (2015) also argued that the corporate brand image indirectly affects consumer loyalty through customer satisfaction. Therefore, it is hypothesized that:

H7: In the mobile telecommunications industry, corporate brand image has a positive impact on customer loyalty through customer satisfaction.

The study aimed to investigate the relationship between corporate brand image and customer loy- 


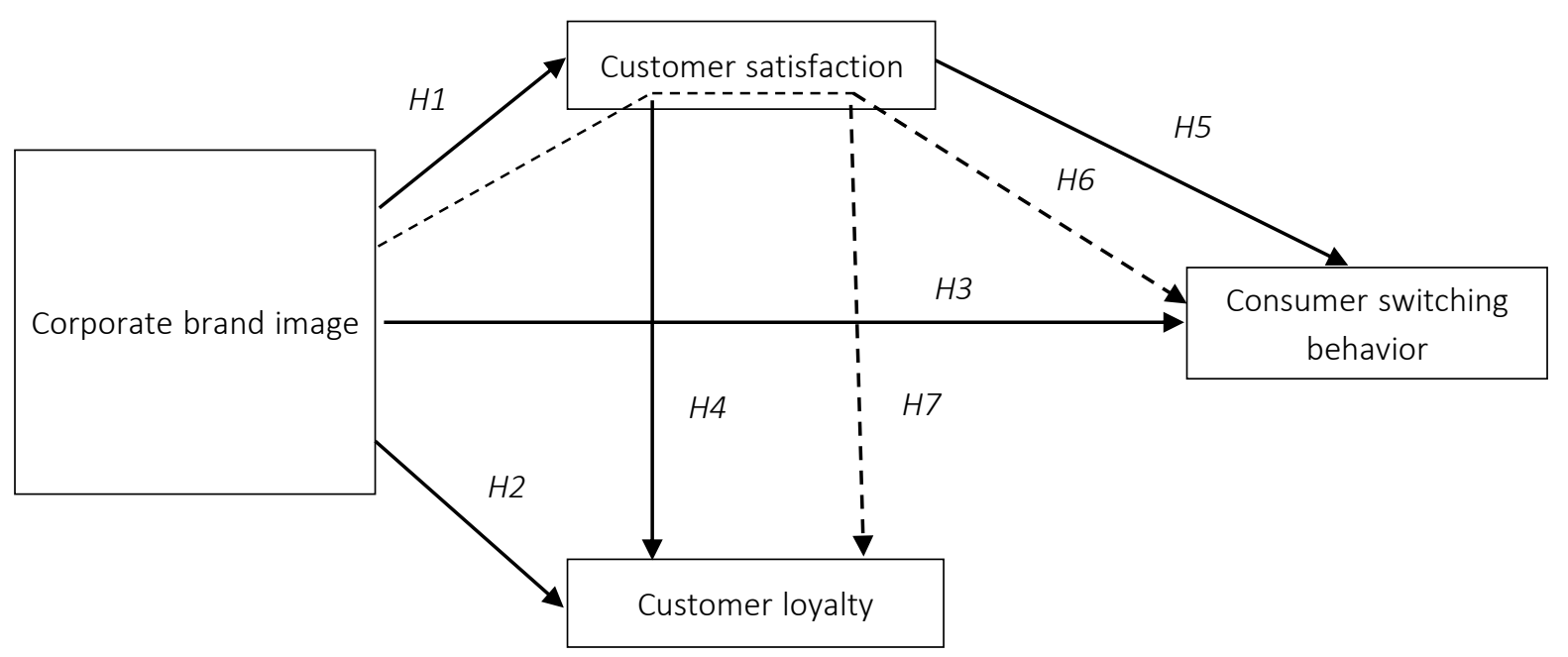

Figure 1. Conceptual framework that was validated in this research

alty, customer satisfaction, and consumer switching in Zimbabwe's mobile telecommunications industry.

\section{RESERCH METHODOLOGY}

\subsection{Research design}

Quantitative research approach was adopted to determine the relationship between the research variables and test the hypotheses. A cross-sectional survey research approach was used since itallowed the researcher to use AMOS (on SPSS) to test the hypotheses (Cresswell, 2014).

\subsection{Target population}

The target population comprised of mobile telecommunication subscribers registered with POTRAZ. Convenience sampling was used since it is more appropriate where there is no population list (Wanninayake \& Chovancova, 2012). By using the Rao software (Rao Soft Inc., 2004), a sample size of 385 participants was determined, with a confidence level of $95 \%$ and margin of error of $5 \%$. The figure mentioned above (385) was divided into 193 participants from Harare and 192 participants from Bulawayo, almost $50 \%$ per city. Adults who are 18 years and above were selected to participate in the study sincethey can make personal purchasing decisions (Wanninayake \& Chovancova, 2012 , p. 8). The respondents were intercepted at the service centers in Harare and Bulawayo since this is where they buy air time (M. Zakersalehi \& A. Zakersalehi, 2012).

\subsection{Research Instruments}

Questionnaires with closed-ended questions were used, and the questions were structured on a seven-point Likert scale, and divided into eight sections.

\section{RESULTS}

\subsection{Reliability}

The corporate brand image measurement scales with 23 items produced an alpha value of 0.870 , customer satisfaction measurement scale with 23 items produced an alpha value of 0.922 , customer loyalty measurement scale with 18 items produced an alpha value of 0.948 , and consumer switching behavior with 20 items also produced an alpha value of 0.908 . The Cronbach's alpha coefficients of measurement scales were above 0.7 , which showed internal consistency (Cresswell, 2014).

\subsection{Validity}

Factor loading sizes are considered to be very important (Hair, William, Babin, \& Anderson, 2014), and high loadings show that they converge on a common position (Hair, Sarstedt, Ringle, \& Gudergan, 2017). Standardized factor loadings are interpreted as correlations between the indicator 
Table 1. Standardized factor loadings

\begin{tabular}{|c|c|c|c|c|}
\hline Construct & Item & Standardized factor loading & CR & $p$-value \\
\hline \multirow{4}{*}{ Corporate brand image } & Customer service & .660 & 6.976 & $* * *$ \\
\hline & Ambiance & .422 & - & - \\
\hline & Confidence & .575 & 6.617 & $* * *$ \\
\hline & Offers value for money & .668 & 7.004 & $* * *$ \\
\hline \multirow{4}{*}{ Customer satisfaction } & Meets my expectations & .860 & & \\
\hline & Satisfactory service & .716 & 13.246 & $* * *$ \\
\hline & Service recovery & .660 & 12.499 & $* * *$ \\
\hline & Problem-solving & .513 & 10.624 & $* * *$ \\
\hline \multirow{3}{*}{ Consumer switching behavior } & Inconvenient & .663 & 10.176 & $* * *$ \\
\hline & Poor service & .756 & 10.529 & $* * *$ \\
\hline & Easy to switch & .714 & - & - \\
\hline
\end{tabular}

Note: CR is fixed; $* * * p<0.001$.

and its factor (Field, 2005), and the standardized loadings should be. 5 or.7 or higher (Hair et al., 2014). If loadings are less than.7, they are considered significant (Hair et al., 2017). According to Hair et al. (2017, p. 694), critical ratios (CRs) for items should be large and above 2 , at a significant level, $p$-values of less than $0.001(p<0.001)$. Table 1 showsthe standardized factor loadings $(\lambda)$, critical ratios (CRs), and $p$-values.

The results in Table 1show that the standard factor loadings of all the factors are above 0.5 , which means that all the items are abovethe minimum cut off point of $((\lambda=0.5)$, and are all considered significant (Hair et al., 2014). Critical ratios for all the items are high enough ( $\mathrm{CR}>2)$, and $p$-values are all significant $(p<0.001)$ (Field, 2005).

\subsection{Discriminant validity}

Discriminant validity is the degree to which two similar concepts are distinct conceptually (Hair et al., 2014). According to Hair et al. (2017, p. 125), discriminant validity is obtained by comparing the average variance extracted (AVE) and squared interconstruct correlations (SICs). Hair et al. (2017, p. 625) further added that discriminant validity is attained when AVE's square root is bigger than
SIC. The results presented in Table 2 show that all the AVEs were greater than the SICs, and in this study, the condition for discriminant validity was practically satisfied (Arkkelin, 2014).

\section{DISCUSSION}

Table 3 summarizes the results of hypotheses testing using standardized regression weight (SRW), critical ratio (CR), and probability (P). Higher positive weights are recommended for observations as they provide reliable information on the functions of regression (Hair et al., 2014). Acceptable SRW values should not be above one (1), although values which are greater than 0.09 are also preferred $(1<\mathrm{SRW}>0.09)$ (Saunders, Lewis, \& Thornhill, 2016). According to Hair et al. (2017), CR values should be higher than 2 , and the significant $p$-value should be less than $0.001(p<0.001)$. For the hypothesis to be accepted, it should fulfill more than one of the mentioned statistics (Saunders et al., 2016).

In summary, $H 1, H 3, H 4, H 5$, and $H 7$ were supported, $H 2$ and $H 6$ were not supported.

The results show a positive relationship between corporate brand image and customer satisfaction

Table 2. AVEs and SICs validity results

\begin{tabular}{|c|c|c|c|c|c|}
\hline Factor & $M \pm S D$ & CB & SA & LO & SB \\
\hline Corporate brand $(C B)$ & $3.69 \pm 0.53$ & 0.51 & 0.54 & 0.53 & -0.33 \\
\hline Satisfaction (SA) & $3.38 \pm 0.72$ & 0.29 & 0.61 & 0.68 & -0.25 \\
\hline Loyalty (LO) & $3.59 \pm 0.84$ & 0.28 & 0.46 & 0.82 & -0.21 \\
\hline Switching behavior (SB) & $2.76 \pm 0.81$ & 0.11 & 0.06 & 0.04 & 0.67 \\
\hline
\end{tabular}

Note: *Diagonal elements in bold represent AVE, numbers below diagonal elements represent SICs, numbers above diagonal elements represent correlations, M represents mean, and SD represents standard deviation. 
Table 3. Hypotheses testing results

\begin{tabular}{|c|c|c|c|c|}
\hline Hypothesis & SRW & CR & $\mathbf{P}$ & Outcome \\
\hline H1: Corporate brand image $\rightarrow$ customer satisfaction & .792 & 6.342 & $<0.001$ & Supported \\
\hline H2: Corporate brand image $\rightarrow$ customer loyalty & .032 & .322 & .748 & Not supported \\
\hline H3: Corporate brand image $\rightarrow$ consumer brand switching & -.459 & -.4938 & .002 & Supported \\
\hline H4: Customer satisfaction $\rightarrow$ customer loyalty & .898 & 10.965 & $<0.001$ & Supported \\
\hline H5: Customer satisfaction $\rightarrow$ consumer switching behavior & -.306 & -4.456 & .800 & Not supported \\
\hline H6: Corporate brand image $\rightarrow$ customer satisfaction $\rightarrow$ consumer switching behavior & .547 & 6.525 & $<0.001$ & Supported \\
\hline H7: Corporate brand image $\rightarrow$ customer satisfaction $\rightarrow$ customer loyalty & .929 & 8.868 & $<0.001$ & Supported \\
\hline
\end{tabular}

(H1). The findings concur with the studies done by Ashraf (2018) and Sallam (2015) that corporate brand image positively affects customer satisfaction. $\mathrm{H} 2$ showed an insignificant relationship between the corporate brand image and customer loyalty. The results are in line with the findings of Sangwan and Bhakor (2018) and Richard and Zhang (2012) who concurred that there is an insignificant relationship between corporate brand image and customer loyalty. $\mathrm{H} 3$ showed a positive relationship between corporate brand image and consumer switching behavior. The results are in line with Hossain (2018) findings, who stressed that corporate brand image has a positive impact on consumer switching behavior. $\mathrm{H} 4$ shows a positive relationship between customer satisfaction and customer loyalty. The results support the findings of Tefera and Govender (2014), Setiwan and Sayuti (2017) who concluded that there is a positive relationship between customer satisfaction and customer loyalty. $\mathrm{H} 5$ shows an in signif- icant relationship between customer satisfaction and consumer switching behavior in the telecommunications sector. The results are in line with the findings of Althonayan, Alhabib, Alrasheedi, Alqahtani, and Saleh (2015) who also found out an insignificant relationship between customer satisfaction and consumer switching behavior. $\mathrm{H} 6$ reveals an indirect relationship between corporate brand image and consumer switching behavior through customer satisfaction. The results are in line with the findings of Srivastava and Sharma (2013) who found out that corporate brand image indirectly impacts on consumer switching behavior through customer satisfaction. $H 7$ shows a positive relationship between corporate brand image and customer loyalty through customer satisfaction. The results support the previous findings of Onyancha (2013) and Sulibhav and Shivashankar (2017) who found out that corporate brand image indirectly affects customer loyalty through customer satisfaction.

\section{CONCLUSION}

The research aimed to discover the impact of corporate brand image on customer satisfaction, customer loyalty, and consumer switching behavior. The results showed a positive relationship between the mobile network's corporate brand image and customer satisfaction. Companies with a good corporate brand image tend to satisfy their customers in the mobile telecommunications industry. The mobile network service providers should put more emphasis on enhancing their corporate image, for example improving the shopping environment, having a better reputation and providing fast and smooth service, etc., to improve satisfaction of customers. The results also showed that the mobile network service providers' image positively affects consumer switching behavior. A good corporate brand image has a great impact on consumer switching behavior. Consumers will not switch service providers if the organisations are offering good services and also have a good brand image. There is also significant relationship between customer satisfaction and customer loyalty. This implies that, when there is customer satisfaction, customers tend to be loyal. Loyal customers make repeat purchases and bring in more revenue to the company. The results also showed that customer satisfaction plays a mediating role in corporate brand image and consumer switching behavior. It, therefore, means that good corporate brand image has a positive effect on customer satisfaction which in turn causes consumers to stop switching mobile network service providers and remain loyal. Switching of brands has a huge negative impact on the rev- 
enues of the company. The results also revealed that corporate brand image indirectly impactson customer loyalty through customer satisfaction in Zimbabwe's mobile telecommunications industry. The companies in the mobile telecommunications sector are recommended to implement good corporate brand image strategies which can improve the levels of customer satisfaction, which in turn help to improve customer loyalty. It is cheaper to maintain a relationship with an existing customer than to look for a new one. However, there is an insignificant relationship between the corporate brand image and customer loyalty, and customer satisfaction does not affect consumer switching behavior in the mobile telecommunications industry. The companies in the mobile telecommunications sector of Zimbabwe are, therefore, recommended to improve the overall brand images of their companies to improve customer satisfaction and reduce consumer switching from one mobile network operator to another.

\section{AUTHOR CONTRIBUTIONS}

Conceptualization: Shylet Chigwende, Krishna Govender.

Data curation: Shylet Chigwende, Krishna Govender.

Formal analysis: Shylet Chigwende.

Funding acquisition: Shylet Chigwende.

Investigation: Shylet Chigwende, Krishna Govender.

Methodology: Shylet Chigwende, Krishna Govender.

Project administration: Shylet Chigwende.

Resources: Shylet Chigwende.

Software: Shylet Chigwende.

Supervision: Krishna Govender.

Validation: Shylet Chigwende.

Writing - original draft: Shylet Chigwende, Krishna Govender.

Writing - review \& editing: Shylet Chigwende, Krishna Govender.

\section{ACKNOWLEDGMENTS}

The authors of this paper greatly appreciate the support and cooperation they received from the Postal and Telecommunications Authority of Zimbabwe (POTRAZ) and research participants during the survey.

\section{REFERENCES}

1. Adonyeva, K. V. (2012). The effect of Brand Image on Customer Brand Loyalty. Bulletin of Scientific Studies Results, 4(3), 188-193. Retrieved from https://cyberlenin$\mathrm{ka}$.ru/article/n/the-effect-of-brandimage-on-customer-brand-loyalty

2. Air Jr, William C., Babin, B. J, \& Anderson, R. E. (2014). Multivariate Data Analysis (7th ed.). Pearson Education Limited.

3. Althonayan, A., Alhabib, A., Alrasheedi, E., Alqahtani, G., \& Saleh, M. A. H. (2015). Customer satisfaction and brand switching intention: A study of mobile services in Saudi Arabia. Expert Journal of Marketing, 3(2), 62-72.
4. Arkkelin, D. (2014). Using SPSS to understand research and dato analysis. Valparaiso University. United States of America. Retrieved from https://scholar. valpo.edu/psych_oer/1/ (accessed on September 9, 2019).

5. Ashraf, S., Ilyas, R., Imtiaz, M., \& Ahmad, S. (2018). Impact of service quality, corporate image and perceived value on brand loyalty with presence and absence of customer satisfaction: A study of four service sectors of Pakistan. International Journal of Academic Research in Business and Social Sciences, 8(2), 452-474. Retrieved from https://ideas.repec.org/a/hur/ ijarbs/v8y2018i2p452-474.html
6. Awogbemi, C. A., Oloda, F. S., \& Osama, C. K. (2012). Modeling Brand Switching in Consumers' Products. Journal of Economics and Sustainable Development, 3(12), 82-86. Retrieved from https://www.iiste.org/Journals/index.php/JEDS/article/view/3474

7. Creswell, J. W., \& Clark, V. L. P. (2014). Designing and Conducting Mixed Methods Research. London: Sage Publications.

8. Das, J. K., Prakash, O., \& Khattri, V. (2016). Brand Image Mapping: A Study on Bathing Soaps. Global Business Review, 17(4), 870-885. https://doi.org /10.1177\%2F0972150916645683 
9. Ene, S., \& Ozkaya, B. (2014). A Study on Corporate Image, Customer Satisfaction and Brand Loyalty in the Context of Retail Stores. Asian Social Science, 10(14), 52. https://doi.org/10.5539/ass. v10n14p52

10. Erkon, S. K., \& Khan, S. (2014). Through the Eye of the Customer. A Study of how Corporate Brand Image Impact on Customer Loyalty and Satisfaction in the Travel Industry (Master Thesis). Uppsala University. Retrieved from http:// www.diva-portal.org/smash/get/ diva2:727988/FULLTEXT01.pdf (accessed on July 15, 2017).

11. Field, A. (2005). Factor Analysis Using SPSS: Theory and Application. Retrieved from http://www.sussex. ac.uk/users/andyf/factor.pdf.

12. Hair Jr, J. F., Sarstedt, M., Ringle, C. M., \& Gudergan, S. P. (2017). Advanced issues in partial least squares structural equation modeling. Sage Publications.

13. Hossain, M., \& Suchy, N. J. (2013). Influence of Customer Satisfaction on Loyalty: A Study on Mobile Telecommunication Industry. Journal of Social Sciences, 9(2), 73 80. Retrieved from https://www. semanticscholar.org/paper/INFLUENCE-OF-CUSTOMER-SATISFACTION-ON-LOYALTY\%3AA-ON-Hossain-Suchy/5a6albbf68 bbebbcdcaaea3366f19315f3f26bd9

14. Kariuki, M. N. (2015). The Impact of Brand Image on Customer Satisfaction in Majorn Supermarkets in Nairobi county (MBA Thesis). University of Nairobi, Kenya. Retrieved from http://erepository.uonbi.ac.ke/ handle/11295/93264 (accessed on July 15, 2017).

15. Karombo, T. (2017). Growth in Zimbabwe's Telecoms Industry. Web Africa Zimbabwe. Retrieved from http://www.itwebafrica.com/ zimbabwe/237535-28-growth-inzimbabwes-telecoms-industry

16. Kotler, P., \& Keller, K. L. (2012). Marketing Management. Pearson.

17. Kotler, F., \& Keller, K. (2015). Marketing Management (15th ed.). Pearson Education, Limited.
18. Lahap, J., Ramli, N. S., Said, N. M., Radzi, S. M., \& Zain, R. A. (2016). A study of brand image towards customer's satisfaction in the Malaysian hotel industry. Procedia-Social and Behavioral Sciences, 224, 149-157. https://doi. org/10.1016/j.sbspro.2016.05.430

19. Lee, J. L., James, J. D., \& Kim, Y. K. (2014). A Reconceptualization of Brand Image. International Journal of Business Administration, 5(4), 1-11. https://doi.org/10.5430/ ijba.v5n4p1

20. Martins, R. C., Hor-Meyll, L. F., \& Ferreira, J. B. (2013). Factors Affecting Mobile Users' Switching Intentions: A Comparative Study between the Brazilian and German Markets. BAR-Brazilian Administration Review, 10(3), 239-262. https://doi.org/10.1590/ S1807-76922013000300002

21. Marumbwa, J. (2013). A Pragmatic Assessment of the Determinants of Consumer Brand Preferences in the Mobile Telecommunications Services Market in Masvingo Urban, Zimbabwe. Management and Administrative Sciences Review, 2(2), 144-155. Retrieved from https://www.academia. edu/4055224/A_Pragmatic_Assessment_of_the_Determinants_ of_Consumer_Brand_Preferences_in_the_Mobile_Telecommunications_Services_Market_in_ Masvingo_Urban_Zimbabwe

22. Neupane, R. (2015). The Effects of Brand Image on Customer Satisfaction and Loyalty Intention in Retail Supermarket Chain UK. International Journal of Social Sciences and Management, 2(1), 9-26. https://doi.org/10.3126/ijssm. v2i1.11814

23. Nhundu, N. (2017). Is Infrastructure Sharing a Game Changer in Zimbabwe Telecoms? Retrieved from https:// static1.squarespace.com/static/52246331e4b0a46e5f1b8ce5/t/ $55 \mathrm{c} 3118 \mathrm{ee} 4 \mathrm{~b} 08204245 \mathrm{~d} 3$ cc2/1438847374304/Infrastructur e+sharing+CCRED+Review6.pdf (accessed on August 12, 2018).

24. Nimako, S. G. (2012). Towards a Comprehensive Definition and Typology of Consumer Switching
Behaviour: Unearthing Research Gaps. Research Journal of Social Science and Management, 2(3), 67-73. Retrieved from https://pdfs. semanticscholar.org/c0d3/3f125 e6665abf8bf4ef21cd2620ac4f9f2 7f.pdf

25. Onyancha, G. K. (2013). The impact of bank brand image on customer satisfaction and loyalty: A case of Kenya commercial bank. European Journal of Business and Management, 21(5), 35-39. Retrieved from https://www.iiste. org/Journals/index.php/EJBM/ article/view/7439

26. Postal and Telecommunications Regulatory Authority of Zimbabwe (POTRAZ) Report (2016). Fourth Quarter Performance Report. Retrieved from http://www.potraz.gov.zw/ wp-content/uploads/2017/03/ Sector_Perfomance_Review_4th_ Quarter_2012.pdf (accessed on July 10, 2018).

27. Postal and Telecommunications Regulatory Authority of Zimbabwe (POTRAZ) Report (2016). First Quarter Performance Report. Retrieved from https:// t3n9sm.c2.acecdn.net/wpcontent/uploads/2017/03/March2016-Zimbabwe-telecoms-reportPOTRAZ.pdf (accessed on June 5, 2017).

28. Rahman, M. S., Haque, M. M., \& Khan, A. H. (2012). A Conceptual Study on Consumers 'Purchase Intention of Broadband Services: Service Quality and Experience Economy Perspective. International Journal of Business and Management, 7(18), 115. Retrieved from https://bit. ly/2TQMPEn

29. Ranjbarian, B., Sanayei, A., Kaboli, M. R., \& Hadadian, A. (2012). An Analysis of Brand Image, Perceived Quality, Customer Satisfaction and Re-purchase Intention in Iranian Department Stores. International Journal of Business and Management, 7(6), 40-48. https://doi.org/10.5539/ ijbm.v7n6p40

30. Richard, J. E., \& Zhang, A. (2012). Corporate Image, Loyalty, and Commitment in the Consumer 
Travel Industry. Journal of Marketing Management, 28(5-6), 568-593. https://doi.org/10.1080/ 0267257X.2010.549195

31. Romani, S., Grappi, S., \&Dalli, D. (2012). Emotions that Drive Consumers Away from Brands: Measuring Negative Emotions Toward Brands and their Behavioral Effects. International Journal of Research in Marketing, 29(1), 55-67. https://doi. org/10.1016/j.ijresmar.2011.07.001

32. Saeed, M., \& Azmi, I. A. G. (2015). Islam, Brand Image and Intention: Influence of Brand Switching Behaviour of Muslim Consumers on Brand Equity. Proceedings of the 2nd international Convention on Islamic management. Retrieved from https://umexpert.um.edu.my/file/publication/00005871_112410.pdf

33. Sallam, M. A. A. (2015). The effect of corporate image on WoM: The Role of Customer Satisfaction and Trust. International Journal of Economics, Commerce and Management, 3(12), 331-340.

34. Sangwan, A. D., \& Bhakar, S. S. (2018). The Effect of Service Quality, Brand Image and Customer Satisfaction on Customer Loyalty: Evidence from Hotel Industry. Prestige International Journal of Management \& IT-Sanchayan, 7(1), 1-15.

35. Saunders, M., Lewis, P., \& Thornhill, A. (2016). Research Methods for Business Students (7th ed.). Pearson Education Limited.

36. Sekyere, A. K. (2015). Customer Satisfaction and Loyalty Assessing; The Moderating Role of Switching Costs in the Insurance Industry (PhD Thesis). University of Ghana. Retrieved from www.ugspace. ug.edu.gh/.../Customer\%20Satisfaction $\% 20$ and $\% 20$ Loyalty $\% 20$ Assessing\%3

37. Setiawan, H., \& Sayuti, A. J. (2017). Effects of Service Quality, Customer Trust and Corporate Image on Customer Satisfaction and Loyalty: An Assessment of Travel Agencies Customer in South Sumatra Indonesia. IOSR Journal of
Business and Management, 19(5), 31-40. Retrieved from https://www.researchgate.net/ publication/317020506_Effects_of_Service_Quality_Customer_Trust_and_Corporate_Image_on_Customer_Satisfaction_ and_Loyalty_An_Assessment_of_ Travel_Agencies_Customer_in_ South_Sumatra_Indonesia

38. Setó-Pamies, D. (2012). Customer loyalty to service providers: Examining the Role of Service Quality, Customer Satisfaction and Trust. Total Quality Management \& Business Excellence, 23(11-12), 1257-1271. Retrieved from https://www.researchgate. net/publication/254348590_Customer_loyalty_to_service_providers_Examining_the_role_of_service_quality_customer_satisfaction_and_trust

39. Srivastava, K., \& Sharma, N. K. (2013). Service Quality, Corporate Brand Image, and Switching Behavior: The Mediating Role of Customer Satisfaction and Repurchase Intention. Services Marketing Quarterly, 34(4), 274291. https://doi.org/10.1080/15332 969.2013.827020

40. Sulibhavi, B., \& Shivashankrar, K. (2017). The Impact of Brand Image on Customer's Loyalty Towards Private Label Brands: The Mediating Effect of Satisfaction. Hubli-Dharwad conglomerate City of Karnataka. International Journal of Marketing and Financial Management, 5(8), 43-50. Retrieved from https://zenodo. org/record/888515\#.XsBCOWgzaUk

41. Sultana, N. (2013). A Relational Study on Consumer Promotion, Price Perception, Service Quality Perception and Brand Loyalty in the Context of Telecommunication Industry in Bangladesh. Retrieved from http:// dspace.bracu.ac.bd/bitstream/ handle/10361/2887/09304056. pdf? sequence $=1$

42. Tefera, O., \& Govender, K. (2015). Hotel Grading, Service Quality, Satisfaction and LoyaltyProposing A Theoretical Model and Relationship. African Journal of Hospitality, Tourism and Leisure,
4, 1-17. Retrieved from https:// www.semanticscholar.org/paper/ Hotel-Grading\%2C-ServiceQuality\%2C-Satisfaction-and-aTefera-Govender/6ff2086001361b 8d8eb4631a3e21cbb2bb42fc5d

43. Tekin, G., Yiltay, S., \& Esra, A. Y. A. Z. (2016). The Effect of Brand Image on Consumer Behaviour: Case Study of Louiss VuittonMoet Hennessy. International Journal of Academic Values Studies, 2, 1-24. Retrieved from https:// www.academia.edu/21457383/ The_Effect_of_Brand_Image_on_Consumer_Behaviour_ Case_Study_of_Louiss_VuittonMoet_Hennessy

44. Van Der Merwe, C. M. (2015). A Comparison between Switching Intention and Switching Behavior in the South African Mobile Telecommunications Industry (Ph.D. Thesis). University of Pretoria. South Africa. Retrieved from https://repository.up.ac.za/ bitstream/handle/2263/53007/ VanderMerwe_Comparison_2016. pdf;sequence $=1$

45. Viriri, P., \& Phiri, M. (2017). Customer Retention Strategies Applicable to Zimbabwe Telecommunication Industry (A Customer Relationship Management Perspective). Journal of Economics, 8(1), 50-53. Retrieved from https:// www.researchgate.net/publication/321222861_Customer_Retention_Strategies_Applicable_to_ Zimbabwe_Telecommunication Industry_A_Customer_Relationship_Management_Perspective

46. Wanninayake, B. W. M. C., \& Chovancova, M. (2012). Consumer ethnocentrism and attitudes towards foreign beer brands: With evidence from Zlin Region in the Czech Republic. Journal of Competitiveness, 4(2), 3-19. Retrieved from https:// www.researchgate.net/publication/272483805_Consumer_Ethnocentrism_and_Attitudes_Towards_Foreign_Beer_Brands_ With_Evidence_from_Zlin_Region_in_the_Czech_Republic

47. Yu, W., \& Ramanathan, R. (2012). Retail Service Quality, Corporate Image and Behavioral Intentions: The Mediating Effects of Customer 
Satisfaction. The International Review of Retail, Distribution and Consumer Research, 22(5), 485-505. Retrieved from https://www.researchgate.net/ publication/263528163_Retail_service_quality_corporate_ image_and_behavioural_intentions_the_mediating_effects_of_ customer_satisfaction
48. Zakersalehi, M., \& Zakersalehi, A. (2012). Consumers 'Attitude and Purchasing Intention toward Green Packaged foods. International Journal of Trade, Economics and Finance, 3(1), 46-51. Retrieved from https:// www.researchgate.net/publication/303184710_Consumers'_attitude_and_purchasing_inten- tion_toward_green_packaged_ foods_A_Malaysian_perspective

49. Zhang, Y. (2015). The Impact of Brand Image on Consumer Behavior: A Literature Review. Open Journal of Business and Management, 3(1), 58-62.

Retrieved from https://m.scirp. org/papers/53297 